\title{
Archaeoacoustic analysis of a dolmen on Mount Freddone, Italy
}

\author{
Prof. Agg. Paolo Debertolis \\ Department of Mediacal Sciences - University of Trieste \\ Super Brain Research Group Organization \\ Trieste, Italy \\ paolo.debertolis@sbresearchgroup.eu
}

\author{
Arch. Natalia Tarabella \\ Super Brain Research Group Organization \\ Florence, Italy \\ natalia.tarabella@sbresearchgroup.eu
}

\author{
Dott. Lorenzo Marcuccetti \\ Super Brain Research Group Organization \\ Florence, Italy
}

\begin{abstract}
Archaeoacoustic analysis provides a complementary method to understand archaeological sites as opposed to a stand alone methodology. Such analysis however, can provide useful insights in cases where there is little or no historical documentation. In such cases, a medical anthropological approach can exploreany connection between the structure and the interaction with the human physiological can provide insight. This study of a Neolithic dolmen located on a peak in the Apuan Alps, Italy has no historical documentation. A medical anthropological approach was applied to the archaeoacoustic results and compared to a dolmen in Portugal. Subsurface vibrations, which have the effect of entraining the brain into a relaxed state, are present. Indeed, the large dolmen stones act like a transducer distributing strong infrasonic vibrations directly above and below the capstone. In the past this site covered a larger area than that found in the present day; on the opposite side of the mountain lie collapsed stones from another dolmen and a nearby quarry provides evidence of where the stones were mined. Both dolmens are orientated towards the equinox.
\end{abstract}

\section{Keywords - archaeoacoustics, dolmen, Apuan Alps}

\section{INTRODUCTION}

Archaeoacoustics is increasingly becoming recognised as a discipline that complements both archeology and anthropology, helping to expand our understanding of why certain sites were revered in ancient times. Within the field of archaeoacoustics a new arguement is starting to emerge:that within prehistoric monuments or temples that are devoid of an acoustically induced resonance phenomena, other phenomenamore naturalin origin are frequentlyfound. Such natural phenomenainclude infrasonic vibrations and magnetic fields both of which can influence the human mind, expanding perception or sensitivity or even enducing altered or 'mysticlal' states of consciousness. After seven years of studying archaeoacoustic phenomena at over fifty sites, Super Brain Research Group (SBRG) ${ }^{1}$ has discovered that they share

\footnotetext{
${ }^{1}$ Super Brain Research Group (SBRG)is an international and interdisciplinary non-profit research organization with legal personality studying the
}

similar properties; natural vibrations or magnetic fields that have a physiological influence on brain waves and consequentlyon ones emotional state, a phenomenon previously observed by researchers: Jahn, Devereux \& Ibison in 1996 [27] and Cook, Pajot \& Leuchter in 2008 [2]. By using modern digital recording techniques, it is now possible to record those non-audible sound frequencies (in the ultrasound or infrasound bands) that can influence human brainwaves. SBRG is also developing a methodology that utilises UV imaging and photography with dedicated software to reveal the presence of magnetic fields through the micro-movements of air, an important breakthrough given the physiological influence magnetic fields have [21, 22]. SBRG's early hypothesiswas that at some archaeological sites, revered for thousands of years, exist measurable natural audio phenomena that give the place unique mystical properties $[3,4,5,6,7,8,9,10,11,12,13,14,15,16,17,18,19,20,21,22,23,28,32$ $33,34]$.

This study looks at two dolmens located on the Apuan Alps in Tuscany dolmens are a rare find in Italy as most of them were destroyed during the Christianisation period. Only one of this pair of dolmens survives today most likely due to its difficult to access location hiddenamongst mountain terrain.

\section{MOUNT FREDDONE DOLMEN ON APUAN ALPS IN ITALY}

The name "dolmen" commonly refers to a Neolithic monument, consisting of two or more vertical standing stones, mounted by a large horizontal capstone. The archaeologist Wilke believes the oldest dolmen in Europe was constructed in the fifth millennium $\mathrm{BC}$, with the more recent large cemetery tombs built around 2,000 BC [36]; according to Fimmen, the oldest forms of the dome-shaped cell dolmen on the island of Crete date back to the proto-Minoan, but remain until at least the Mycenaean period. Crete has no early dolmens [25].

archaeoacoustic properties of ancient sites and temples throughout Europe and Asia from 2010 (www.sbresearchgoup.eu). 
Their function is still subject to discussion today. Some dolmens host individual or collective tombs, including furnishings dating to the Neolithic or pre-Neolithic periods; others contain remains of embossed and sometimes painted embellishments. Many archaeological findings (offerings, altars, galleries, etc.) suggest that such monuments might have had a religious function. In Italy, many dolmens and other Neolithic monuments were totally destroyed by later civilizations or by the Church, as a result only a few remains today, even less so in a reasonable condition (Fig. 1). In contrast Portugal's dolmens escaped the ravages of the Church, and were in some sense preserved (Fig. 2).

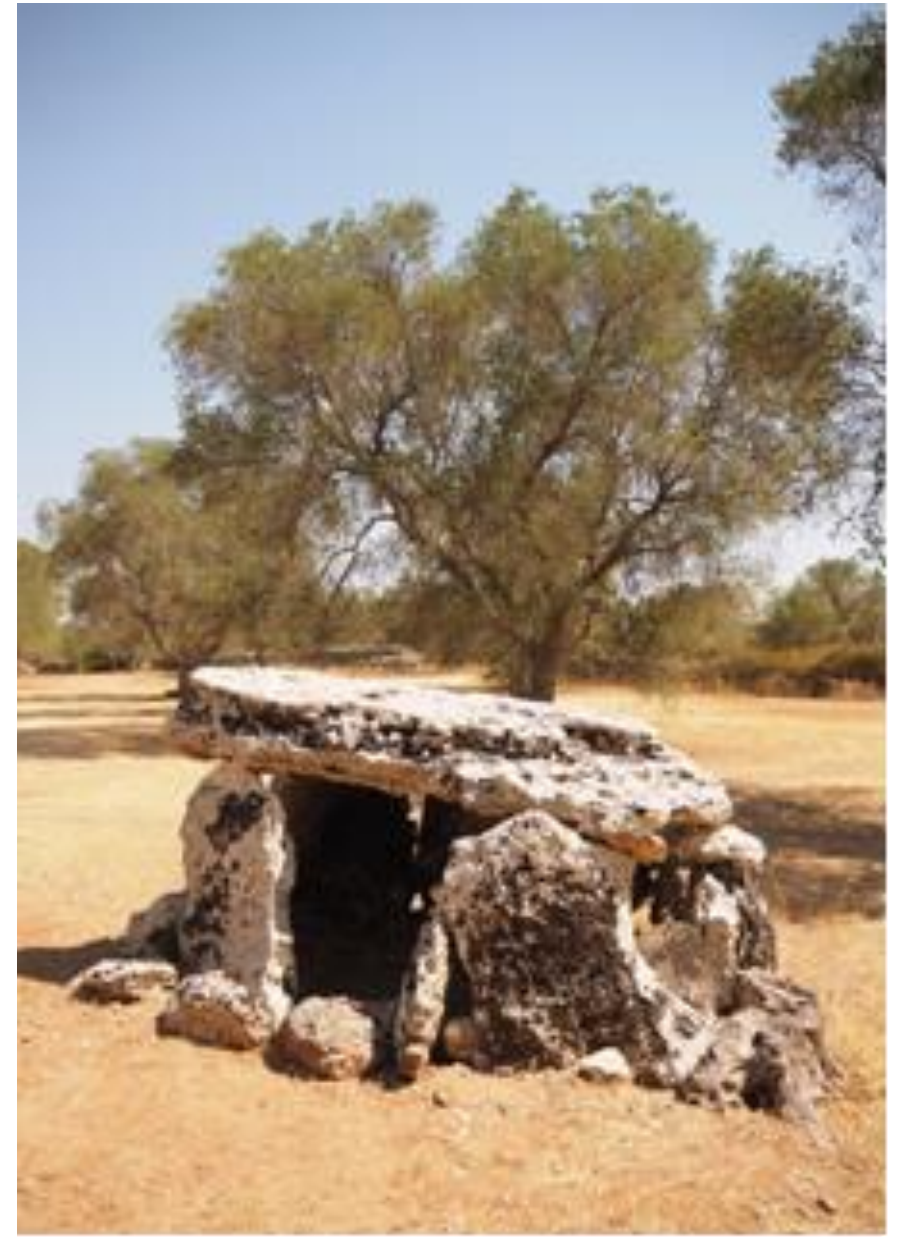

Figure 1. Dolmen "Placa", Melendugne, Lecce, Italy.

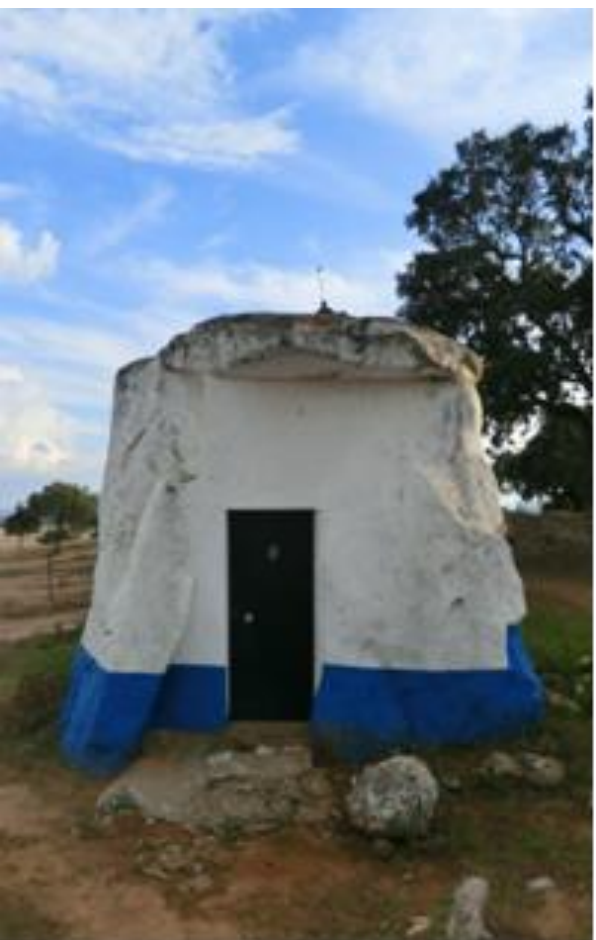

Figure 2. A dolmen transformed in a small church in Portugal.

The Apuan Alps, High Versilia and Garfagnana are part of the Apuan Alps Park (Fig. 3), it is a region rich with petroglyphs and archaeological finds which are, in part, unknown and not precisely datable. These areas have been inhabited since Neolithic times, but the meaning and the reason for the petroglyphs and other artifacts such as sacred altars and thrones is unknown. However these can be viewed as a stone atlas to provide some insight as to the historical roots of this region. To the south west lies the island of Corsica culturally linked to the Apuan Alps through a common identity matrix written about by classical historians. Corsica presents some examples of dolmens which like those in the Apuan Alps appear to fall into the latter typology, although these have only been partially studied.

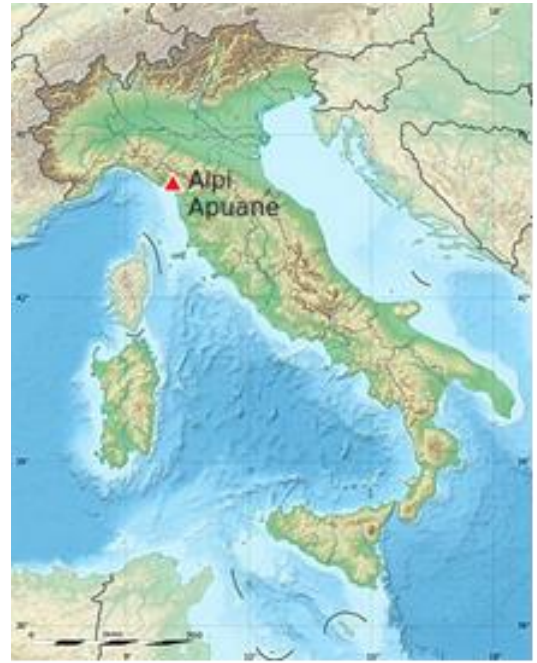

Figure 3. A map showing the location of the Apuan Alps, Italy. 


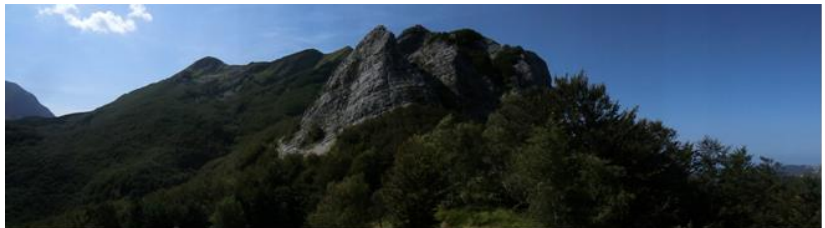

Figure 4. Mount Freddone, Apuan Alps.

The most important artifact today is the dolmen situated close to the summit of ancient Mount Freddone (1,489m) (Fig. 4 ), in the municipality of Stazzema (Lucca). The alpine pastures of the ancient village of Terrinca at one time encompassed this area. Mount Freddone was at one time mined for copper by Eneolithic Bronze Age man, and later by the Apuan-Ligurians who extracted minerals until the end of the nineteenth century. The dolmen (Fig.5 and Fig.6) is oriented towards the Spring Equinox sunset, in 2015Calzolari assumed that it could have been built to observe the spring equinoctial phenomena [1]. He also suggests its horizontal capstone forms a gnomon, which relates to the semantics of the TAU symbol representing life or resurrection in ancient times.

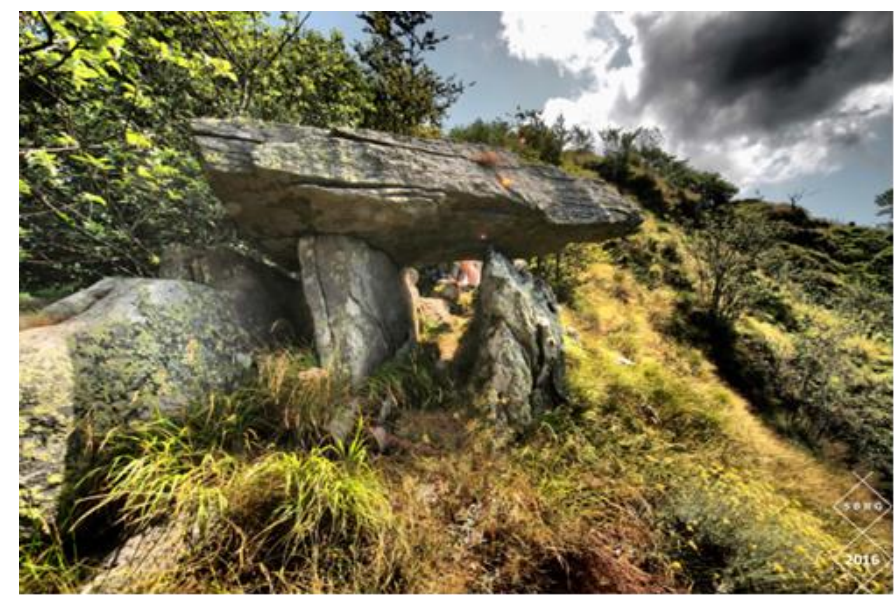

Figure 5. Mount Freddone dolmen taken from East.

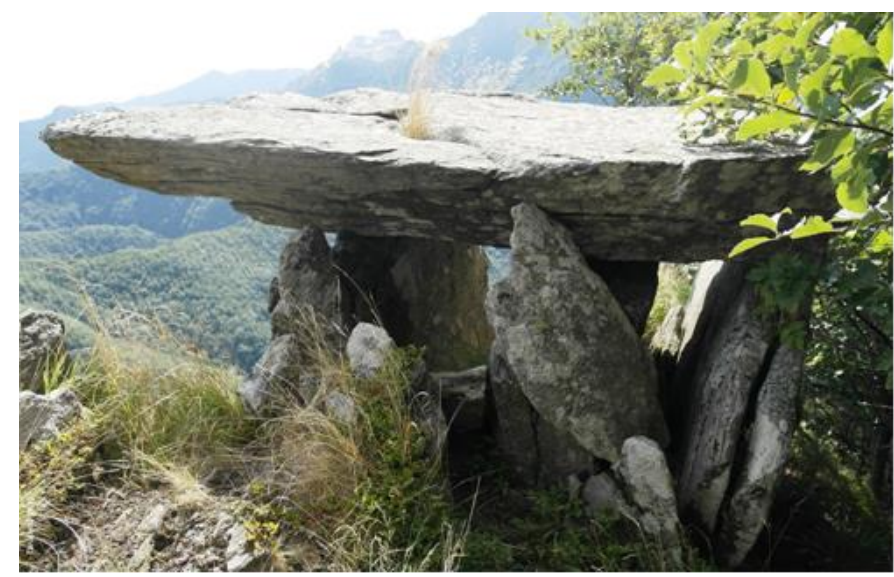

Figure 6. Mount Freddone dolmen from a different angle of view (West).
The dolmen is oriented towards the Springsunset Equinox when the sun sets on the summit of Altissimo mountain, which is situated in front of Mount Freddone. The light fully illuminates its interior chamber, with the upper beam oriented exactly in a north-south direction. Today Italy has very few examples of dolmens in such good condition. It was probably saved from destruction due to its difficult access even today; if this was a tomb, why was it placed in such an inaccessible location? A stone quarry is situated close to the summit and the strata revealssome missing stones. Is it possible the ancient civilization quarried the dolmen stones from these original layers before transporting them to their current location? (Fig.7).

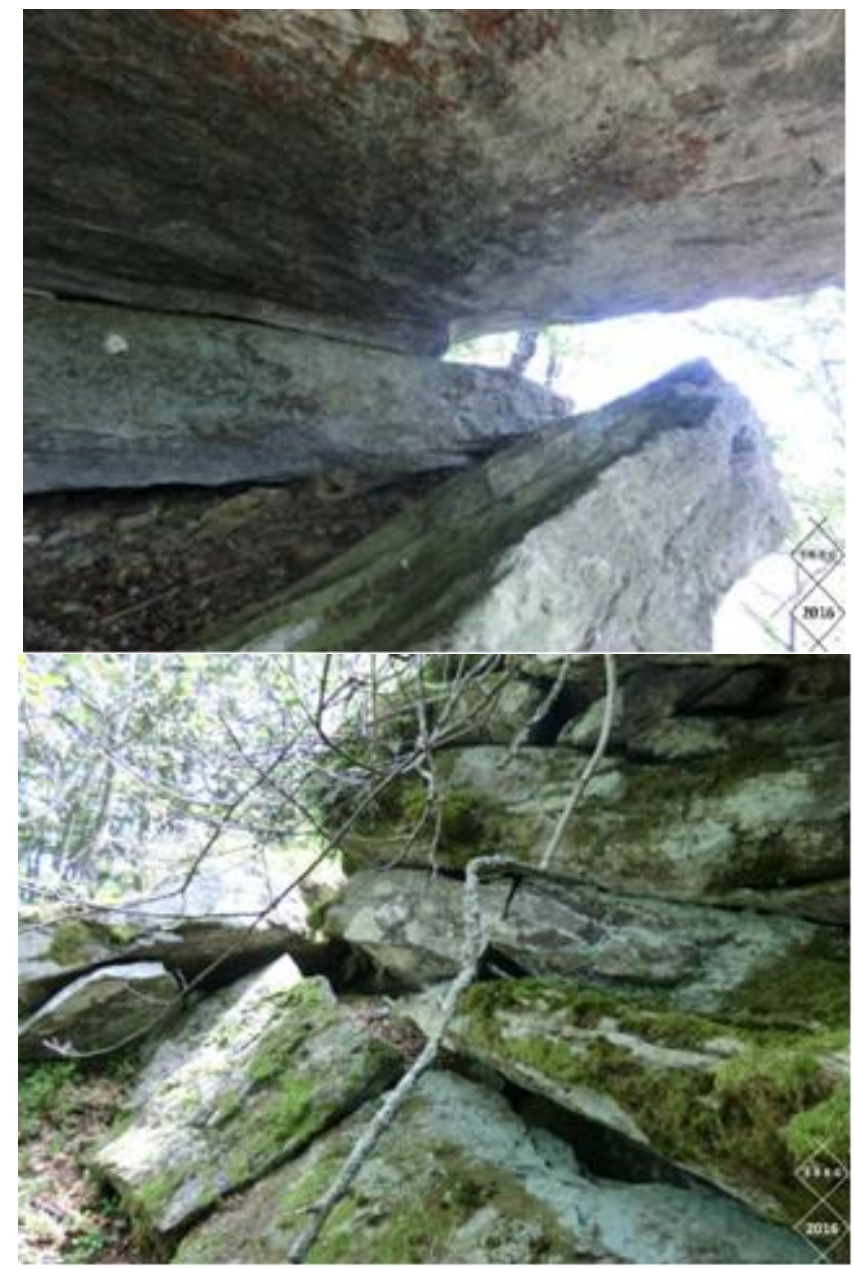

Figure 7. The quarry on the top of Mount Freddone, showing some evidence of stone extraction.

On the other side of the mountain another dolmen can be found, but unfortunately it has been destroyed. One plausible reason for this is likely due to an earthquake in which the two pillar stones opened up causing the horizontal capstone to fall (Fig. 8). This area is close to a geological fault and the stones are set in a very soft soil. The path to the dolmen on the summit of Mount Freddone is marked by a great number of menhirs (Fig. 9), such artifacts are typical of a "ceremonial landscape". It is worth noting that local myths passed on in the oral tradition, speak of mystical rituals at this site in the ancient 
past. For these reasons an interdisciplinary investigation into the archaeoacoustic characteristics of this site was carried out.

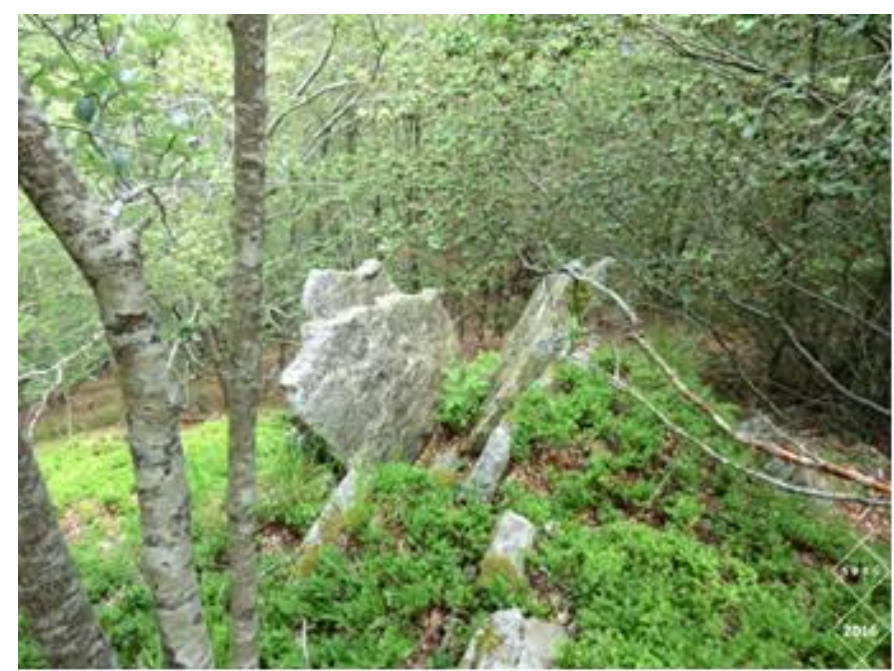

Figure 8. The destroyed dolmen on the opposite side of the summit on Mount Freddone. The capstone appears to have fallen between the opened stone pillars.

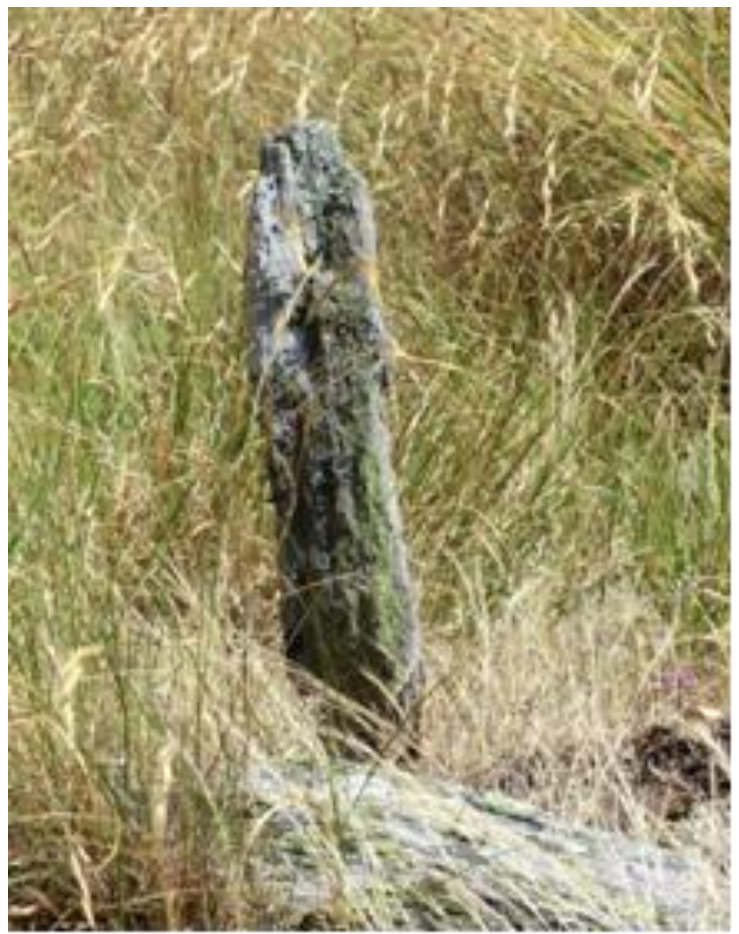

Figure 9. One of the small menhirs lining the path to the summit of Mount Freddone, forming part of the ceremonial landscape.

\section{MATERIALS AND METHODS}

Equipment for the sound recordings consisted of two types of dynamic high-end microphones extended in the ultrasound frequency range, with a digital portable recorder (Tascam DR-
680 of TEAC Group, with a maximum sampling rate of 192KHz). Professional studio microphones with a wide dynamic range and a flat response at different frequencies (Sennheiser MKH 8020, response Frequency $10 \mathrm{~Hz}$ $60.000 \mathrm{~Hz}$ ) with shielded cables (Mogami Gold Edition XLR) and gold-plated connectors (Fig. 10) were also used.

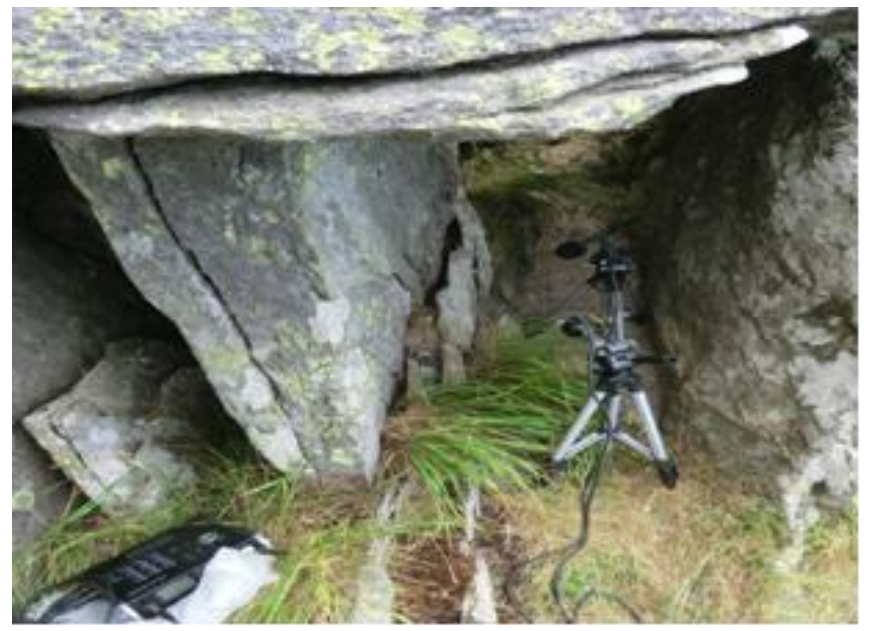

Figure 10. Sound recording equipment $\&$ set-up below the dolmen.

Before recording a spectrum analyzer (Spectran NF3010from the German factory Aaronia AG) was used to detect the presence of any electromagnetic phenomena which could have influenced the results (Fig. 11).

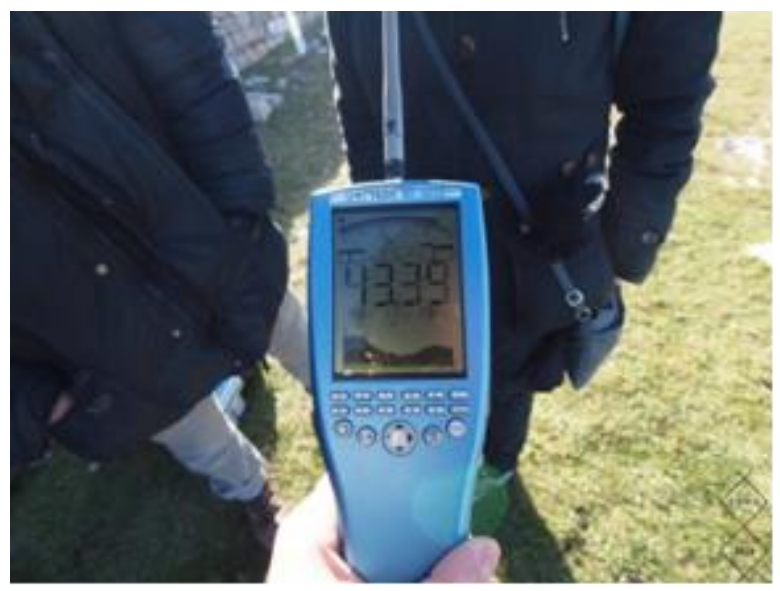

Figure 11. Spectran NF-3010 from the German factory Aaronia AG.

Archaeoacoustic measurements at Monte Freddone dolmen were carried out at two locations: in the chamber below the dolmens capstone and at a distance of approximately 500 meters to the West. It was impossible to measure to other directions because the deep ravine. To avoid surface vibrations, the microphones were placed on isolated tripods directly on the top and below the capstone. Only the vibration from the air was recorded (there was no wind present throughout the recordings), and there was a 10 minute pause between each recording. Once the mircophones were in position, prerecording tests were conducted by clapping to determine if the 
microphones were affected by any external environmental noise.

\section{RESULTS}

High volume infrasounds (low frequencies) in the $7-12 \mathrm{~Hz}$ frequency range (with an average of $8 \mathrm{~Hz}$ ) were recorded inside the dolmen at a volume of $-37-56 \mathrm{db}$ (with an average of $46 \mathrm{db}$ ). Previous research at other archaeological sites found similar vibrations. A constant frequency in the audible band of around $65 \mathrm{~Hz}$ with a volume of around $-62 \mathrm{db}$, was also present; this most likely source of this was ambient noise coming from a small river in the valley below (Fig. 13). Those individuals who consider themselves to be sensitive state they often sense such vibrations as unspecified energy emanating from underfoot, and other physiological effects on the body relaxing the brain in particular. Such infrasound frequencies are able to enter the brain without passing through the hearing organ, entraining the brainwave rythm into an Alpha-Theta state.

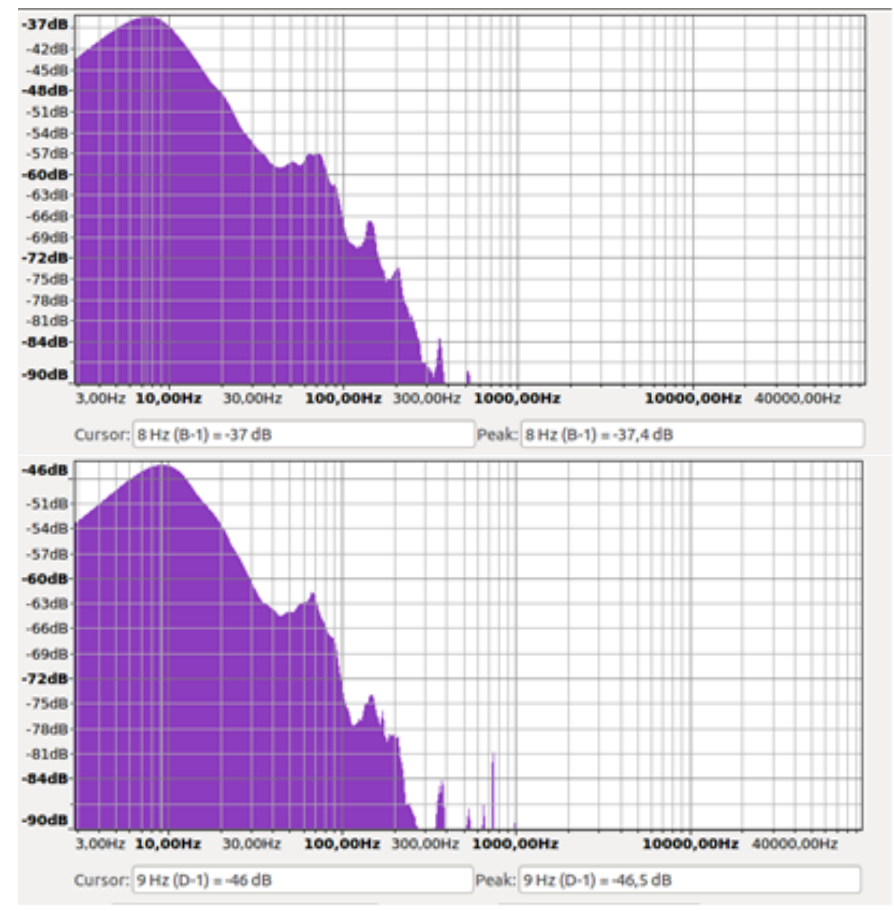

Figure 13. The extraordinary low frequency peak present in all recordings taken at Monte Freddone dolmen.

Some clarification of the characteristics of these results in respect of the measured volume should be mentioned: in that there is a distinction between using decibels to measure sound pressure levels as opposed to signal levels.Sound Pressure Levels (SPL) are a measurement of air pressure which is caused by sound or noise, this results in physical forces moving against the diaphragm of a microphone and in the acoustic environment this translates to volume. Measurements of this nature are usually expressed as dB SPL (decibels of sound pressure level) and are measured in positive numbers. For example a rock concert can reach $110 \mathrm{db}$ or a jackhammer $100 \mathrm{db}$, moreover a person whispering is around $20-30 \mathrm{db}$. When dealing with signal levels, decibels are used a little differently. In this case, $0 \mathrm{~dB}$ is the highest signal level achievable without any distortion; all signal levels below this point are then represented as negative numbers. A volume fader may be labeled with a "0", part way up to mark the point at which that fader is neither boosting nor attenuating the signal.

The measurements taken at Mount Freddone dolmen show a level of $-37 \mathrm{db}$ which is a loud volume despite the fact it is inaudible due to it being below the range of human hearing (infrasound).

\section{DISCUSSION}

It is possible that the stones that form the dolmen act as a transducer of vibrations coming from underground. Above and especially inside the dolmen the vibrations have a good transmission to the air. Similar results were obtained in Alatri where using a slightly different setup the polygonal stones that formed the original wall of the acropolis on top of Alatri acted as transducers [12, 23]. A scientific paper published in 2015 [10], highlighted the world of physics has been fast approaching the arena of neuro-sciences and offering an alternative perspective to quantum vibrations. The aim of this research was to build on earlier archaeoacoustic research to investigate the relevance of conscious studies from the Microtubule Neurological System (MNS) perspective along with other related biological materials. Neurophysiologists have neglected to consider materials beyond the neuron considering them only as particular cells. However recent discoveries within the MNS field have shown that proteins and other materials, (as the discovery of a resonance chain that connects DNA to the brains final architecture) make it possible to better understand brain activity. In particular the discovery of a resonance chain that covers an astonishing frequency bandwidth of several orders of magnitude within the brain, that could bring both neurophysiologists and consciousness researchers to a unified approach and better understanding of brain responses (VlaamCultuuhuis de BrakkeGrond, 2014) [35]. Further, the discovery by Hameroff and Penrose [26] of quantum vibrations in the microtubule architecture located within the cerebral cells, influenced SBRG theory around the natural environment found at ancient sites. They proposed that brain waves recorded by electro encephlography (EEG) originate from the brains neurons microtubule structure which vibrates. Penrose and Hamerof consider that even thoughts could originate from this system and quantum vibrations are orchestrated by sinaptic connections (Orchestrated Objective Reduction or "Orch OR" theory) [26]. This theory was initially highly critised because many researchers considered the brain too complicated to host delicate quantic processes. But recently Orch OR theory was confirmed by Anirban Bandyopadhyay's research group with the Intistute of Science of Materials in Tsukuba (Japan) [30,31] and by Eckenhoff's teamfrom the University of Pennsylvania[24]. In particular the latter research demonstrated that general anestesya can act on the microtubule system of neurons without interfering with other cells functions, therby operating on the conscience without influencing non-conscience brain functions. Moreover, brain memory is now considered a deformation of the resonance chain. Penrose, Hameroff and Bandyopadhyay explored their theories during a session on "Microtubules and the Big Consciousness Debate" at the Brainstorm Sessions, a public three-day event at the BrakkeGrond in Amsterdam 
(Netherlands) January 16-18, 2014 [30,31,35]and concluded that "Consciousness depends on a harmonic vibration of microtubules inside neurons, similar to certain kinds of Indian music, but unlike Western music which is harmonic vibration" (Hameroff) (VlaamCultuuhuis de BrakkeGrond, 2014). Further they found resonance vibrations not only generate electric activity (as detected by EEG) but also light (Rahnamaet al., 2011) [29]. This aspect was confirmed by Debertolis \& Gullà in 2015 [10]. Is it also possible that some very low vibrations can influence the state of consciousness in anyone exposed to these frequencies, through a process of entrainmentwhich cause the microtubules inside the neurons to vibrate. SBRG research group has demonstrated that sound vibrations can influence brain activity without passing through the hearing organ [6], therefore it can be supposed that infrasounds at certain frequencies have a strong effect on the human state of mind altering cognitive perception. Similar infrasonic vibrations were discovered at a number of ancient sites analysed between 2010 to 2017 (Debertolis et al., 2012-2018). Below a dolmen located at ParqueMegalitico Dos Coureleiros, Castelo de Vide, in Portugal (fig. 14) is discussed. This site features several dolmens, but only the dolmen known as "Anta 2" is in good condition.
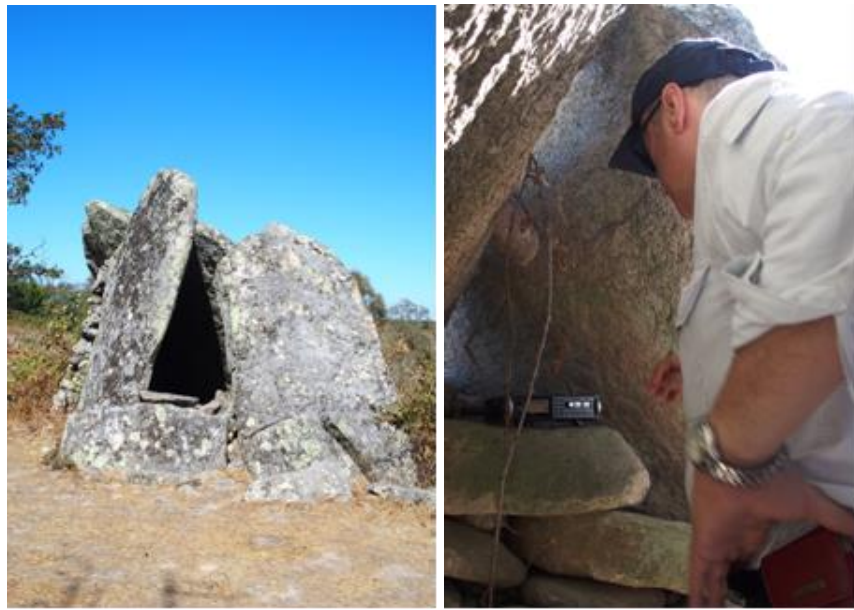

Figure 14. Anta 2 dolmen, Parque Megalitico DosCoureleiros in Portugal. Left: the dolmen today; Right: the sound recording set up inside the dolmen.

During this research it was observed that inside the dolmen those natural infrasonic vibrations present actually reverberate more strongly inside rather than outside the dolmen which in turn affects the brain. Radon gas radioactivity originating from underground is higher inside the dolmen compared to outside the dolmen. It is more than three time higher, but below dangerous levels (Fig. 15).

A peak of $28 \mathrm{~Hz}$ at $-34 \mathrm{db}$ (Fig.16) in the audible band was discovered, very similar to other sites studied in Europe and Anatolia, for example Xaghra Stone Circle and Tarxien Temples in Malta(Debertolis, Earl \& Tarabella, 2017) [20], Epidaurus in Greece or Gobekli Tepe in South-East Anatolia (Debertolis, Gullà \& Savolainen, 2017)[22].

It appears that this dolmen works in a similar manner to a transducer of vibrations that originate from the subsoil and are able in some way to affect human brain, as we showed in various previous scientific papers (Debertolis et al 2012-2018).

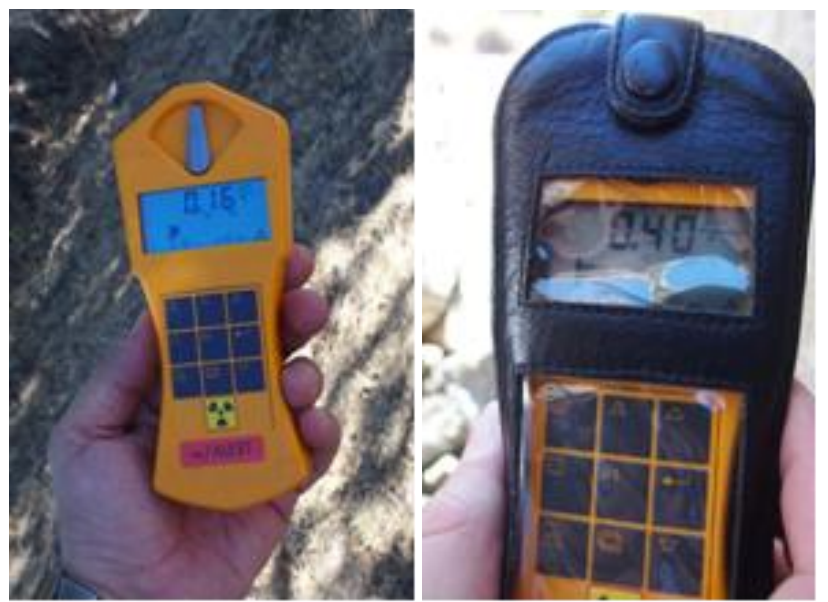

Figure 15. Radioactivity measured by Geiger counter. Left: outside the dolmen it is $0.16 \mu \mathrm{Sv} / \mathrm{h}$, that is normal in an open space for Portugal; Right: inside the dolmen the radioactivity is three times than inside, it is $0.40 \mu \mathrm{Sv} / \mathrm{h}$.

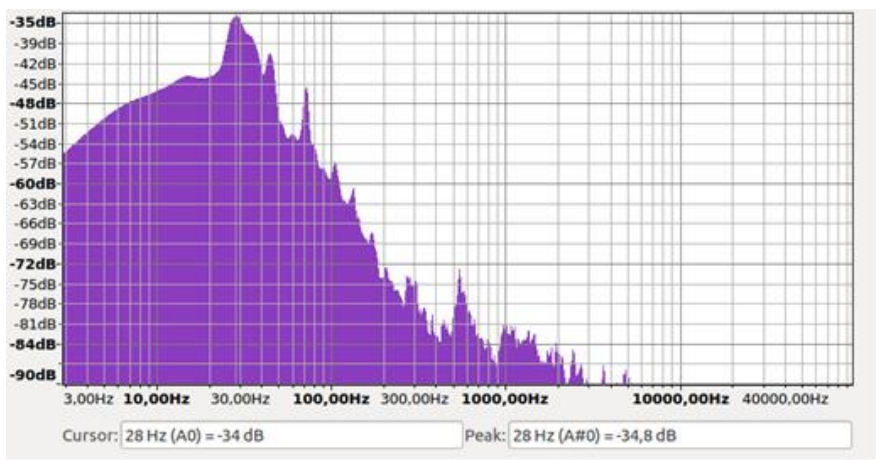

Figure 16. The audio spectrum taken inside the Portuguese dolmen. There is a peak at $28 \mathrm{~Hz}$ at $-34 \mathrm{db}$ in audible band.

\section{CONCLUSION}

Research at Monte Freddone dolmen found those vibrations discovered share similar characteristics with those found at other sacred sites throughout Europe.

In the absence of historical sources anthropological or archaeological research can beaidedthrough better understanding of the characteristics of an ancient sacred site. In this case,both dolmen sites show how it might be possible to reach an altered state of consciousness from the vibrations originatingfrom natural phenomena, which acts on brain wave activity in particular conditions. Further, ancient people appeared to be aware of this phenomia and purposefully placed stones in locations where natural vibrations were amplified.. There are also various scientific papers which confirm the connection between brain activity and natural physical phenomena (Debertolis et al 2012-2018) $[3,4,5,6,7,8,9,10,11,12,13,14,15,16,17,18,19,20,21,22,23,28$, $32,33,34]$. 
Monte Freddone dolmen (Fig. 17) is unlikely to be a tomb because no burial artefacts have been found (Calzolari, 2015) [1]. But its true purpose is hinted at from the lined menhirs path that leads to the space on the top of the mountain. The audio analysis shows some characteristics capable of affecting states of conscious, because the volume of infrasound pressure was very high.

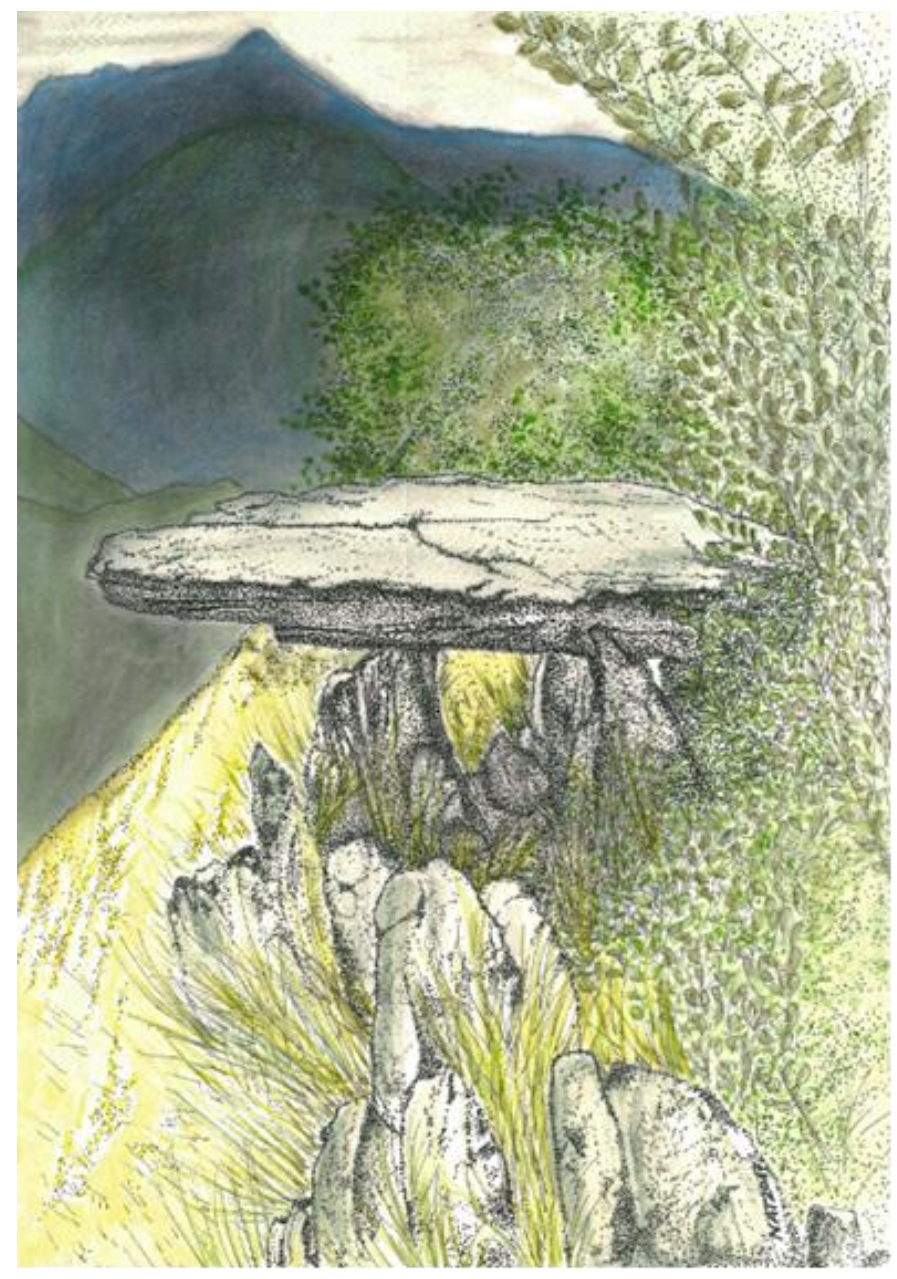

Figure 17. Mount Freddone dolmen as in image taken during our study (picture by N. Tarabella).

This suggests the capstone acts as an excellent transducer. Moreover the presence of a second dolmen on the opposite side of MonteFreddone summit is interesting. It suggests an astronomical connection with sacred rituals more impressive for the infrasound coming from below the soil.

\section{ACKNOWLEDGMENT}

This scientific research was illustrated as presentation at "Archaeoacoustics III",The third international multidisciplinary conference on The Archaeology of Sound, 05 - 08 October 2017, Tomar, Portugal. Our warmest thanks go to the organizer Linda Eneix of Old Temple Study Foundation, Tampa, USA, for her great professionality and to all the
Conference Committeee. The authors are very grateful for the support received by non-profit scientific organization Super Brain Research Group institute (SBRG) for the develop of this archaeoacoustic research.

\section{REFERENCES}

[1] E. Calzolari, "Il dolmen del Monte Freddone" in "Il Cielo in Terra ovvero della giusta distanza", 1st edition, Padova University Press, University of Padova, Italy, 2015: pp. 53-62.

[2] I.A. Cook, S.K. Pajot, A.F. Leuchter, "Ancient Architectural Acoustic Resonance Patterns and Regional Brain Activity", Time and Mind, Volume 1, Number 1, March 2008 , pp. 95-104 (10).

[3] P. Debertolis, H.A. Savolainen, "The phenomenon of resonance in the Labyrinth of Ravne (Bosnia-Herzegovina). Results of testing", Proceedings of ARSA Conference (Advanced Research in Scientific Areas), Bratislava (Slovakia), December, 3-7, 2012, pp. 1133-1136.

[4] P. Debertolis, N. Bisconti, "Archaeoacoustics in ancient sites" Proceedings of the "1st International Virtual Conference on Advanced Scientific Results" (SCIECONF 2013), Zilina (Slovakia) June, 10-14, 2013, pp. 306-310.

[5] P. Debertolis, N. Bisconti, "Archaeoacoustics analysis and ceremonial customs in an ancient hypogeum", Sociology Study, Vol.3 no.10, October 2013, pp. 803-814.

[6] P. Debertolis, G. Tirelli, F. Monti: "Systems of acoustic resonance in ancient sites and related brain activity". Proceedings of Conference "Archaeoacoustics I: The Archaeology of Sound", Malta, February 1922, 2014, pp. 59-65.

[7] P. Debertolis, D. Gullà, F. Richeldi, "Archaeoacoustic analysis of an ancient hypogeum using new TRV camera (Variable Resonance Camera) technology", Proceedings of the "2nd International Virtual Conference on Advanced Scientific Results" (SCIECONF 2014), Zilina (Slovakia) June, 9 - 13, 2014, pp. 323-329.

[8] P. Debertolis, N. Bisconti, "Archaeoacoustics analysis of an ancient hypogeum in Italy", Proceedings of the Conference "Archaeacoustics I: The Archaeology of Sound", Malta, February 19-22, 2014, pp. 131-139.

[9] P. Debertolis, A.Tentov, D.Nikolic, G. Marjanovic, H.Savolainen, N. Earl, "Archaeoacoustic analysis of the ancient site of Kanda (Macedonia)", Proceedings of the 3rd Conference ARSA (Advanced Research in Scientific Areas), Zilina (Slovakia), December, 1-5, 2014, pp. 237-251.

[10] P. Debertolis, D. Gullà, "Anthropologic analysis of human body emissions using new photographic technologies", The 3rd International Virtual Conference on Advanced Scientific Results (SCIECONF 2015), Zilina (Slovakia), May, 25-29, 2015, pp. 162-168.

[11] P. Debertolis, F. Coimbra, L. Eneix, "Archaeoacoustic Analysis of the HalSaflieni Hypogeum in Malta", Journal of Anthropology and Archaeology, Vol. 3 (1), 2015, pp. 59-79.

[12] P. Debertolis, D. Gullà, "Archaeoacoustic analysis of the ancient town of Alatri in Italy", British Journal of Interdisciplinary Science, September, Vol. 2, (3), 2015, pp. 1-29.

[13] P. Debertolis, M. Zivic, "Archaeoacoustic analysis of Cybele's temple, Roman Imperial Palace of Felix Romuliana, Serbia", Journal of Anthropology and Archaeology, Vol. 3 (2), 2015, pp. 1-19.

[14] P. Debertolis, D. Nicolic, G. Marianovic H. Savolainen, N. Earl, N. Ristevski, "Archaeoacoustic analysis of Kanda Hill in Macedonia. Study of the peculiar EM phenomena and audio frequency vibrations", Proceedings of the 4th Conference ARSA (Advanced Research in Scientific Areas), Zilina (Slovakia), November 9-13, 2015, pp.169-177.

[15] P. Debertolis, N. Earl, M. Zivic: "Archaeoacoustic Analysis of Tarxien Temples in Malta", Journal of Anthropology and Archaeology, Vol. 4 (1), June 2016, pp. 1-22.

[16] P. Debertolis, D. Gullà: "Preliminary Archaeoacoustic Analysis of a Temple in the Ancient Site of Sogmatar in South-East Turkey. Proceedings of Conference 'Archaeoacoustics II: The Archaeology of Sound', Istanbul (Turkey), Oct 30-31 Nov 1, 2016, pp. 137-148.

[17] P. Debertolis, D. Gullà: "New Technologies of Analysis in Archaeoacoustics", Proceedings of Conference "Archaeoacoustics II: 
The Archaeology of Sound', Istanbul (Turkey), Oct 30-31 Nov 1, 2015, pp. 33-50.

[18] P. Debertolis, D. Gullà: "Healing aspects identified by archaeoacoustic techniques in Slovenia", Proceedings of the '3rd International Virtual Conference on Advanced Scientific Results' (SCIECONF 2016), Zilina (Slovakia), June 6-10, 2016, pp. 147-155.

[19] P. Debertolis, D. Gullà, F. Piovesana: "Archaeoacoustic research in the ancient castle of Gropparello in Italy", Proceedings of the 5th Conference ARSA (Advanced Research in Scientific Areas), Zilina (Slovakia), November, 7-11, 2016, pp. 98-104.

[20] P. Debertolis, N. Earl, N. Tarabella: "Archaeoacoustic Analysis of Xaghra Hypogeum, Gozo, Malta, Journal of Antropology and Archaelogy, June 2017, Volume 5, Number 1, 2017, pp. 1-16.

[21] P. Debertolis, D. Gullà: "Archaeoacoustic exploration in Montebello Castle, Rimini, Italy", Arts and Humanities Open Access Journal, vol. 1 n. 1: 00003, DOI: 10.15406/ahoaj.2017.01.00003.

[22] P. Debertolis, D. Gullà, H. Savolainen: "Archaeoacoustic Analysis in Enclosure D in the GöbekliTepe in South Anatolia, Turkey", Proceedings in Scientific Conference "5thHASSACC 2017 - Human And Social Sciences at the Common Conference", Slovakia, Žilina, September 25-29, 2017, pp. 107-114.

[23] P. Debertolis, D. Gullà, N. Tarabella, L. Marcuccetti, "Definitive Results o Archaeoacoustic Analysis at Alatri Acropolis, Italy", Proceedings of Conference 'Archaeoacoustics III: The Archaeology of Sound', Tomar (Portugal), Oct 5-8, 2018, in press.

[24] D.J. Emerson, B.P. Weiser, J. Psonis, Z. Liao, O. Taratula, A. Fiamengo, X. Wang, K. Sugasawa, A. Smith, R.G.Eckenhoff, I.J.Dmochowski, "Direct modulation of microtubule stability contributes to anthracene general anesthesia", J. Am. Chem. Soc. 2013.S

[25] D. Fimmen: "Kretisch-mykenischeKultur", $2^{\mathrm{a}}$ ed., Lipsia, 1924

[26] S. Hameroff, R. Penrose, "Reply to criticism of the 'Orch OR qubit' 'Orchestrated objectve reduction' is scientifically justified". Physics ofLife Reviews (Elsevier) 11 (1), 2014, pp. 94-100.

[27] R.G. Jahn, P. Devereux, M. Ibison: "Acoustical Resonances of Assorted Ancient Structures", J. Acoust. Am Soc Vol.99 No.2, February 1996, pp.649-658.
[28] I. Lovasz, P. Debertolis, "Archaeoacoustic Approach of the Rotunda in Bény", Proceedings of Conference "Archaeoacoustics III: The Archaeology of Sound', Tomar (Portugal), Oct 5-8, 2018, in press.

[29] M. Rahnama, I. Bokkon, J. Tuszynski, M. Cifra, P. Sardar, V. Salari, "Emission of Biophotons and Neural Activity of the Brain", Cornell University Library, 2011, (Handle: http://arxiv.org/vc/arxiv/papers/1012/1012.3371v1.pdf ).

[30] S. Sahu, S. Ghosh, K. Hirata, D. Fujita, A. Bandyopadhyay, "Multi-level memory-switching proprieties of a single brain microtubule", Appl. Phys. Lett. 102, 123701 (2013).

[31] S. Sahu, S. Ghosh, B. Ghosh, K. Aswani, K. Hirata, D. Fujita, A. Bandyopadhyay, "Atomic water channel controlling remarkable properties of a single brain microtubule: correlating single protein to its supramolecular assembly." BiosensBioelectron 2013, 47, pp.141-148.

[32] N. Tarabella, P. Debertolis, "Archaeoacoustics in Archaeology", Proceedings of 19th International Conference and Assembly of the Experts of the Foundation Romualdo Del Bianco "Heritage for Planet Earth 2017 - Smart Travel, Smart Architecture and Heritage Conservation and its Enjoyment for Dialogue", Florence, Italy, 11-12 March 2017, pp. 240-246.

[33] N. Tarabella, P. Debertolis, D. Gullà, L. Marcuccetti, "Fireplace and holy altar in Curiceta at Apuan Alps, Italy", Proceedings of Conference 'Archaeoacoustics III: The Archaeology of Sound', Tomar (Portugal), Oct 5-8, 2018, in press.

[34] N. Tarabella, P. Debertolis, D. Gullà, R. Romero, "The ancient knowledge of sound. Archaeoacousticanalisys of the Pyramid of Bomarzo and the surrounding areas in Lazio, Italy", Proceedingsof 20th International Conference and Assembly of the Experts of the Foundation Romualdo Del Bianco "Heritage for Planet Earth 2018 - One Planet, One Origin, Many Cultures, One Shared Destiny, Or None!", Florence, Italy, 3-4 March 2018, in press.

[35] Vlaam Cultuuhuis de Brakke Grond, "Adventure Consciousness Conference and Debate. A closer look into the fundamental principles of neuroscience and its replication", Brain Storming Session 2014, Amsterdam, 16th January 2014.

[36] G. Wilke, P. Bosch Gimpera, H. Gummel, V. Duhn, Roeder, P. Thomsen: in "Reallexicon der Vorgeschichte", VIII, 1927, s. v. Megalith-Grab. 